\title{
STRENGTHENING THE COMPETENCES OF FUTURE SPECIALISTS IN ACCORDANCE WITH THE DEVELOPMENT TRENDS OF CROP PRODUCTION
}

\author{
Veronica PRISACARU1, PhD in Economics, Associate Professor, \\ State Agrarian University of Moldova \\ Tatiana SEVCIUC', PhD in Economics, Associate Professor, \\ State Agrarian University of Moldova \\ Grigore BALTAG 3 , PhD in Economics, Associate Professor, \\ State Agrarian University of Moldova
}

DOI: https://doi.org/10.36004/nier.es.2020.2-04

JEL Classification: E24, I25, J24, J43, J45, 013

UDC: 378.663(478)

\section{ABSTRACT}

Under the current conditions, marked by a flexible and turbulent environment, balancing the demand and supply of the labor market is one of the basic factors for sustainable development. In this context, identifying the most effective tools to adapt the supply of professional education to the needs of the sectors is an important step towards achieving the goals of sustainable development. Even if considerable efforts as well as relevant methodological tools are required, the process of harmonizing the requirements of the sectors and the content of professional education programs is particularly important and represents a decisive factor in achieving the sustainable development goals. The main purpose of this investigation was to highlight the essence and application aspects of the sectoral approach in anticipation of the necessary competences, as well as to operate with this tool in order to identify trends and problems related to crop production in the Republic of Moldova and to make changes necessary for improving the curricula. In order to achieve the proposed goal, the following methods were used: synthesis of methodological recommendations and good practices for applying the sectoral approach in anticipating competences; economic-statistical analysis; systematic approach; classification method; structural-logical method; generalization; deduction; drawing conclusions and reasoning, including using the objectives tree technique. The research resulted in explaining the essence and particularities of sectoral approach in terms of advantages and disadvantages, analysis of the agricultural production sector, especially crop production in the Republic of Moldova and formulating recommendations for improving agricultural study programs.

Keywords: agriculture, competences, crop production, education, labor market, sectoral approach.

În condițiile actuale de dezvoltare a societății, în virtutea mediului extrem de flexibil și turbulent, echilibrarea cererii și ofertei pieței muncii reprezintă unul din factorii de bază ai dezvoltării durabile. În acest context, identificarea celor mai eficace instrumente de adaptare a ofertei educației profesionale la necesitățile sectoarelor reprezintă un pas important în direcția atingerii obiectivelor dezvoltării durabile. Chiar dacă se impun eforturi considerabile și se solicită instrumente metodologice relevante, procesul de armonizare a cerințelor sectoarelor și conținutului programelor de educație profesională este deosebit de important și reprezintă un factor decisiv al atingerii obiectivelor dezvoltării durabile. Scopul de bază al prezentei investigații a constat în elucidarea esenței și aspectelor aplicative ale abordării sectoriale în anticiparea competențelor necesare, precum și operarea cu acest instrument pentru a identifica tendințele și problemele aferente producției vegetale în Republica Moldova și a proiecta unele intervenții curriculare în raport cu deficiențele constatate. În vederea atingerii scopului propus, s-au utilizat metodele: sinteza recomandărilor metodologice și bunelor practici de aplicare a abordării sectoriale în anticiparea competențelor; analiza economico-statistică; abordarea sistemică; metoda clasificării; metoda structural-

\footnotetext{
${ }^{1}$ ID ORCID 0000-0002-2952-6888 e-mail:v.prisacaru@uasm.md

2 ID ORCID 0000-0001-7886-4165 e-mail: sevciuctatiana@mail.ru

${ }^{3}$ ID ORCID 0000-0002-7220-8922 $₫$ e-mail: g.baltag@uasm.md
} 
logică; generalizarea; deducția; formularea de concluzii și raționamente, inclusiv și prin utilizarea tehnicii arborelui obiectivelor. Cercetarea s-a soldat cu explicarea esenței și particularităților de aplicare a metodelor și tehnicilor de abordare sectorială prin prisma avantajelor și dezavantajelor, analiza sectorului producției agricole și, distinct, a producției vegetale în Republica Moldova și formularea recomandărilor de perfecționare a programelor de studii cu profil agrar.

Cuvinte-cheie: agricultură, abordare sectorială, competențe, educație, producție vegetală, piața muncii.

В современныхусловиях развития общества, в силу чрезвычайно гибкой и турбулентной среды, балансирование спроса и предложения на рынке труда является одним из основных факторов устойчивого развития. В этом контексте, выявление наиболее эффективных инструментов для адаптации системы профессионального образования к потребностям секторов является важным шагом на пути к достижению целей устойчивого развития. Даже если требуются значительные усилия и соответствующие методологические инструменты, процесс согласования требований секторов и содержания программ профессионального образования особенно важен и является решающим фактором на пути достижения целей устойчивого развития. Основная цель данного исследования заключается в изложении сути и практических аспектов секторального подхода в проектировании необходимых навыков, а также в применении данного инструмента для выявления тенденций и проблем в развитии растениеводства в Республике Молдова и разработки предложений по улучшению соответствующих учебных программ. Для достижения поставленной цели, использовались следующие методы: синтез и обобщение методических рекомендаций и передовой практики применения секторального подхода; экономико-статистический анализ; системный подход; метод классификации; структурно-логический метод; дедукция, формулировка обоснований и выводов, в том числе с использованием техники дерева целей. В результате исследования были разъяснены сущность и особенности применения методов и приемов секторального подхода с точки зрения преимуществ и недостатков, проведен анализ сектора сельскохозяйственного производства и, в отдельности, растениеводства в Республике Молдова, а также сформулированы рекомендации по совершенствованию программ сельскохозяйственного профессионального образования.

Ключевые слова: навыки, образование, растениеводство, рынок труда, секторальный подход, сельское хозяйство.

\section{INTRODUCTION}

The economic and social prosperity of each state, as a primary strategic objective, must be examined under the influence of all determinants. Among them, while some are manifested by direct and quantifiable impact, others, including the quality of trained specialists, face the difficulty of measuring the exerted influences. However, this does not diminish the significance of the efforts needed to increase this impact, thus creating conditions to achieve the expected development goals.

Education, along with lifelong learning, are recognized today as pillars of the development process by virtue of their multiple effects: promoting the interests of individuals, businesses, and, implicitly, of the economy and society; reducing the vulnerability of young people on the labor market; eradicating poverty; increasing social inclusion; facilitating economic growth, etc. [ILO. Skills for trade and economic diversification; ILO, 2004; ILO, 2010. A Skilled Workforce for Strong, Sustainable and Balanced Growth; Savelieva and Prodan, 2018]. The extent to which the professional education system, in its turn, will be able to generate the above-mentioned effects depends on its ability to meet current and future requirements of the sectors for which the final products are intended (qualified human resources). In other words, the best possible balance of the demand for skilled labor and the supply of the professional education system is required, which, in its turn, must meet the following requirements: relevance, efficient organization and management, high quality results [ILO, 2010. Upskilling out of the Downturn]. Compliance with these requirements in relation to the educational offer is particularly important, taking into account that demand patterns are constantly and similarly changing in most countries under the influence of demographic factors, globalization, international competition and technological change [Cedefop, 2016]. Thus, it is obvious that the modernization of 
the educational system represents an urgent necessity in response to the challenges and needs of the economy diversification, the transition to new technological structures, the expansion of a competitive presence on the external markets, the increased competitiveness of the economically active population and business entities etc. [Bogush, 2017:103].

\section{LITERATURE REVIEW}

Under the current conditions, because of the increasing flexibility of the business and living environment, governments are called upon to strengthen competence development systems to ensure that the skills and qualifications offered can bridge the gap that may exist between the world of education and training on the one hand, and the world of work on the other hand [ILO. Skills for trade and economic diversification; ILO, 2010. A Skilled Workforce for Strong, Sustainable and Balanced Growth]. Although it has been in use for decades, the term „competence” has gained a greater interest in educational research, psychology and neighboring disciplines in the last few years, generated by the globalization of the labor and educational markets. Thus, since the end of the 1980s, the implementation of new governmental intervention strategies in the educational systems has led to a stronger focus on "outputs" and "outcomes" at all educational levels, from elementary, up to vocational and adult education. The outcomes - or the value added to them - are used as criteria of the educational systems` productivity, as well as of the related educational institutions` quality and of the learning achievement of the individuals [Klieme et al., 2008:3].

Among different existing definitions, those that are based on the functional approach may be highlighted and, consequently, may be used for a large-scale assessment of the educational outcome. So, according to Weinert (1999) "the concept of competence refers to an individually or interindividually available collection of prerequisites for successful action in meaningful task domains". Based on the previous approach, Klieme and Leutner came with a working definition, as "contextspecific cognitive dispositions that are acquired by learning and needed to successfully cope with certain situations or tasks in specific domains" [Klieme et al., 2008:9]. In a more concise but consistent manner the competences are defined by the International Labour Organization as "knowledge, skills and knowhow applied and mastered in a specific context" [ILO, 2004]). It can be observed that the term "competence", according to the definition given by the International Labour Organization, is larger, than the term "skills", the latter representing a component of "competence". However, many documents and studies refer to the term skills in a broader meaning: knowledge, abilities, know-how.

The analysis of the demand and supply of competences in order to balance them can be done in various ways, among which the sectoral approach is getting a growing relevance. The term "sector" in this context is used to define specific areas of economic activity. The sectoral approach is defined as „one which aims at changing skills needs from the perspective of a particular sector" [Wilson et al., 2016:13]. It operates from a forward-looking perspective, and provides information about sector's development and growth opportunities based on its global competitive position and market development and, on this basis, anticipates the skills that the sector most needs to strengthen for future success [ILO, 2016]. Currently, the sectoral approach in anticipating competences is a significant and effective tool, widely accepted and promoted internationally. The history of implementing the sectoral approach begins at the end of the last century. Initially, some countries, such as France, began to make labor forecasts (a long time ago) based on indicative economic planning. Most other countries have been making such forecasts since the 1970s and 1980s. Later the sectoral studies became part of that process. For example, Portuguese studies began in the late 1990s. The United Kingdom imposes itself by setting up Sector Skills Councils in 2002, and the EU began publishing the results of sectoral studies in 2008 (Wilson et al., 2016:28). The experience of wide implementation of sectoral studies has been widely taken over by the countries in transition, having obtained remarkable results in the Czech Republic, Romania, Estonia [Wilson et al., 2016:30-31]. The particularly high significance of sectoral studies is evidenced by their persistence in most attempts to predict the future of the labor market [ILO Skills for trade and economic diversification; Gregg and Nayef, 2015; Breuer, 2012], representing a dimension of macroeconomic models for skill anticipation. For most countries, the sector is in the centre of systems providing education and training, especially vocational education. Germany, for example, has managed to establish strong links between 
employers and providers of education and training [Wilson et al., 2016:28].

The sectoral approach to competence forecasting is based on a series of tools and techniques, which are set out in Figure 1.
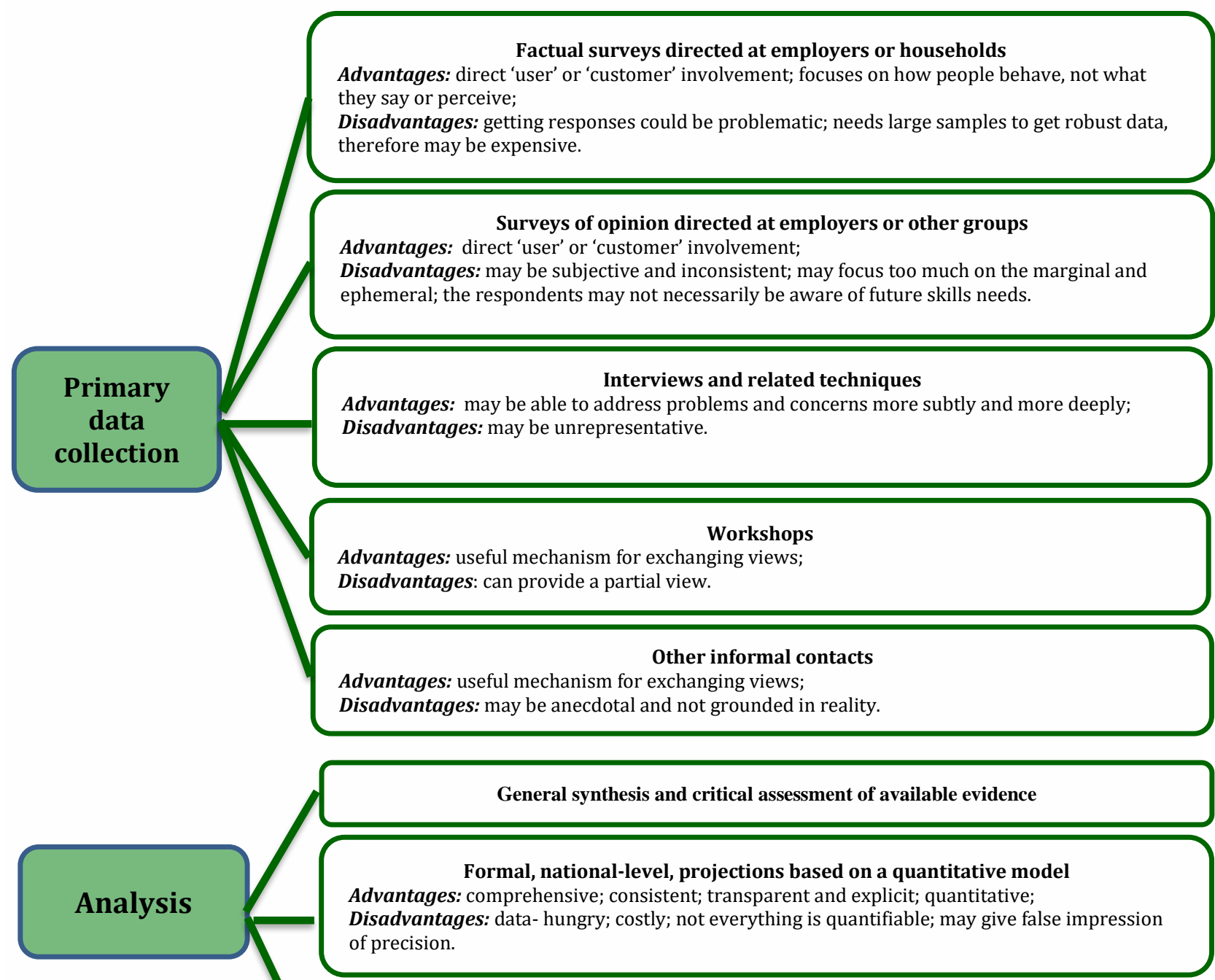

Partial projections based on quantitative models

(for example focusing on individual sectors or occupations)

Advantages: transparent and explicit; quantitative; targeted;

Disadvantages: not everything is quantifiable; may give false impression of precision; partial analysis may be biased.

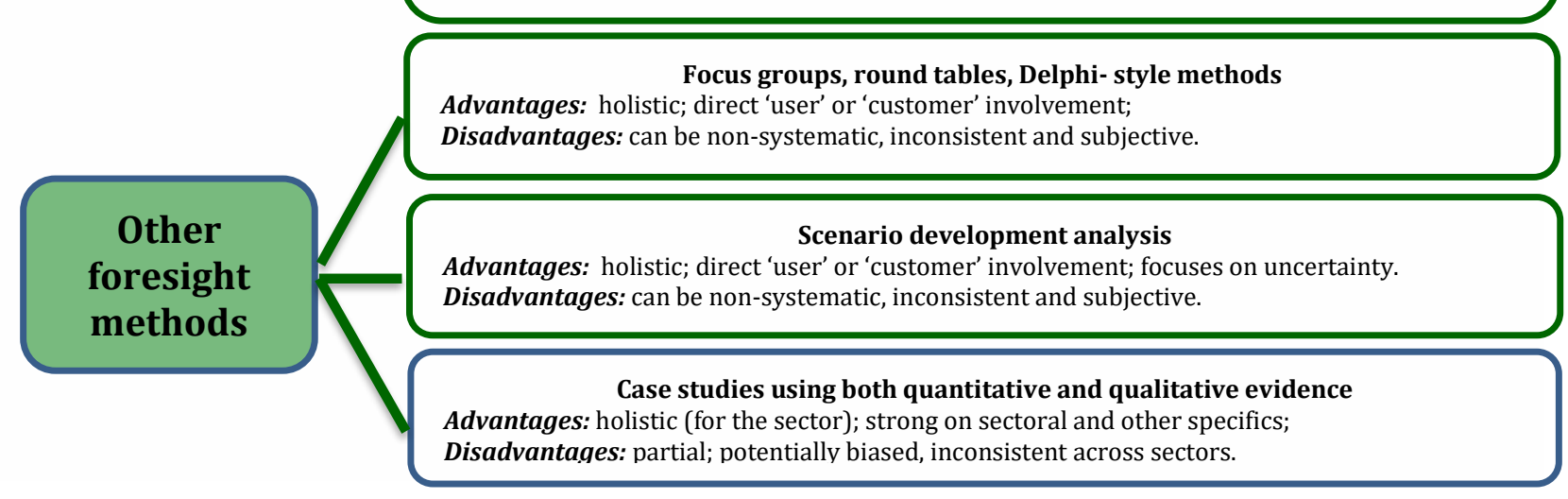

Figure 1. Tools and techniques used in competence anticipation

Source: Developed by the authors based on [Wilson et al., 2016: 26-27]. 
The effectiveness of the competence anticipation process depends on the extent to which the optimal combination of different tools will be made, each of which has, in addition to advantages, some limitations, as shown in Figure 1. The main factors determining the content and methodology of the sectoral approach and, respectively, the possible choices regarding the tools and techniques to be applied, are set out in Figure 2.

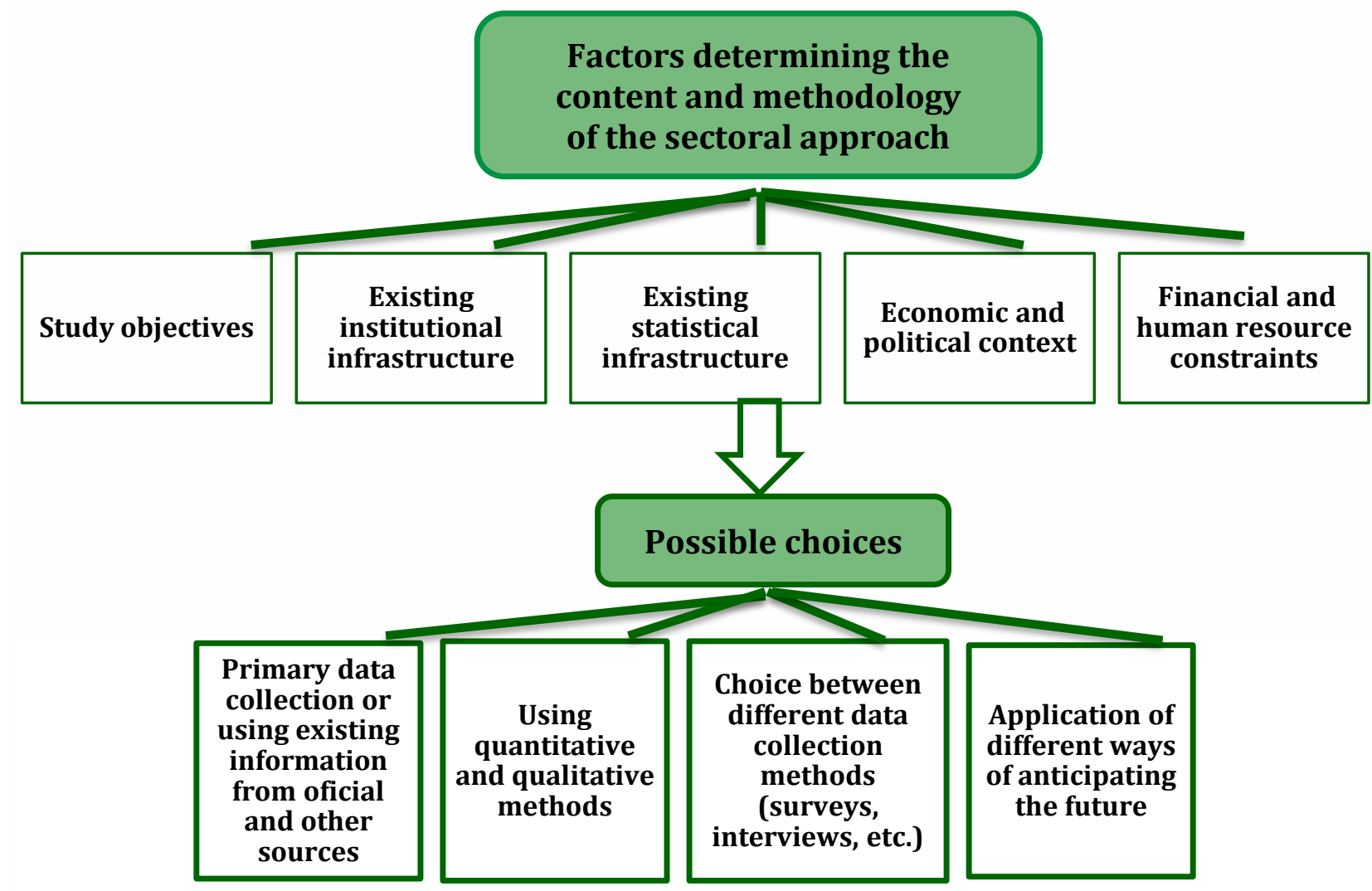

Figure 2. Factors determining the content and methodology of the sectoral approach in anticipating competencies

Source: Developed by the authors based on [Wilson et al., 2016:13].

Another important landmark of the sectoral analysis as a tool for anticipating competences is the active and productive involvement of stakeholders, including: employers and their representatives; employees and their representatives; the state; professional education and training providers; potential labor market participants (students, their parents, career guidance services) [Wilson et al., 2016:13-14].

In addition to the tools and techniques applied, other important factors for the success of the sectoral analysis are highlighted, namely: commitment and support from beneficiaries, their active involvement (especially of the employers); representativeness of enterprises of various sizes (small, medium and large); availability of financial and human resources; skills and expertise in implementation; relevant data availability [ILO. Skills for trade and economic diversification; ILO, 2004; Wilson et al., 2016:14].

\section{RESEARCH METHODOLOGY AND RESOURCES}

The present investigation was carried out by following several consecutive steps:

1. Synthesis study of the conceptual approaches of the sectoral analysis and of the good practices in applying the sectoral analysis in the competence anticipation;

2. Assessment of general trends in the evolution of agricultural production and, distinctly, of crop production in the Republic of Moldova;

3. Identification of factors that reduce crop production efficiency; 
4. Identification of the competences to be improved within the professional education programs with agricultural profile in the context of issues related to crop production;

5. Prediction of the medium and long-term effects of proposed interventions.

The assumed tasks were performed by using the following methods: investigating different resources regarding the sectoral approach in competence anticipation; analysis of the crop production in terms of quantitative and qualitative indicators; identification of problems related to crop production efficiency and, implicitly, to agricultural production in general; deducing the directions of intervention in professional education programs with agricultural profile and forecasting their effects in the medium and long term by using the objectives tree technique; formulation of reasoning and final recommendations on the necessary interventions in the programs.

The sources of information were: a series of strategic documents, scientific and analytical publications on the researched subject, statistical data available on the official website of the National Bureau of Statistics of the Republic of Moldova.

The present investigation was carried out within the scientific project "Predictive approaches to increasing the quality of skills in agricultural higher education based on the partnership with the business environment", no. 20.80009.0807.41.

\section{RESEARCH RESULTS AND DISCUSSIONS}

The need to focus efforts on improving the quality of the specialists for the agricultural sector is justified both by the recognized significance of the sector for the economic and social development of the Republic of Moldova, and by the absence of visible positive trends in its performance evolution. Moreover, climate change, economic crises (example: the current crisis caused by the Covid pandemic) amplify the pressures on agricultural balances and education budgets.

At the current stage the agricultural professional education system in the Republic of Moldova consists of educational institutions of three levels: secondary technical vocational education, postsecondary technical vocational education and higher education. The productivity of the respective system can be evaluated by a series of indicators, the most relevant being the number and the quality of specialists trained for the national economy. With reference to the basic quantitative aspect of agricultural education performance, there exists the problem of continuous reduction of the number of students (Figure 3) and, as a result, of the reduction of the number of graduates (Figure 4). Thus, as shown in figure 4, there is a visible descendent trend in the number of graduates from postsecondary technical vocational education institutions and from higher education institutions in the „Agricultural sciences” field. With reference to the graduates from secondary technical vocational education institutions, we find out an insignificant increase in 2019. However, with the reduction of the number of students in the investigated field, it is obvious that in the future the number of graduates will drop.

We have a positive situation only with reference to the field of "Veterinary Medicine" higher education, where growth trends are manifested in both the number of students and graduates.

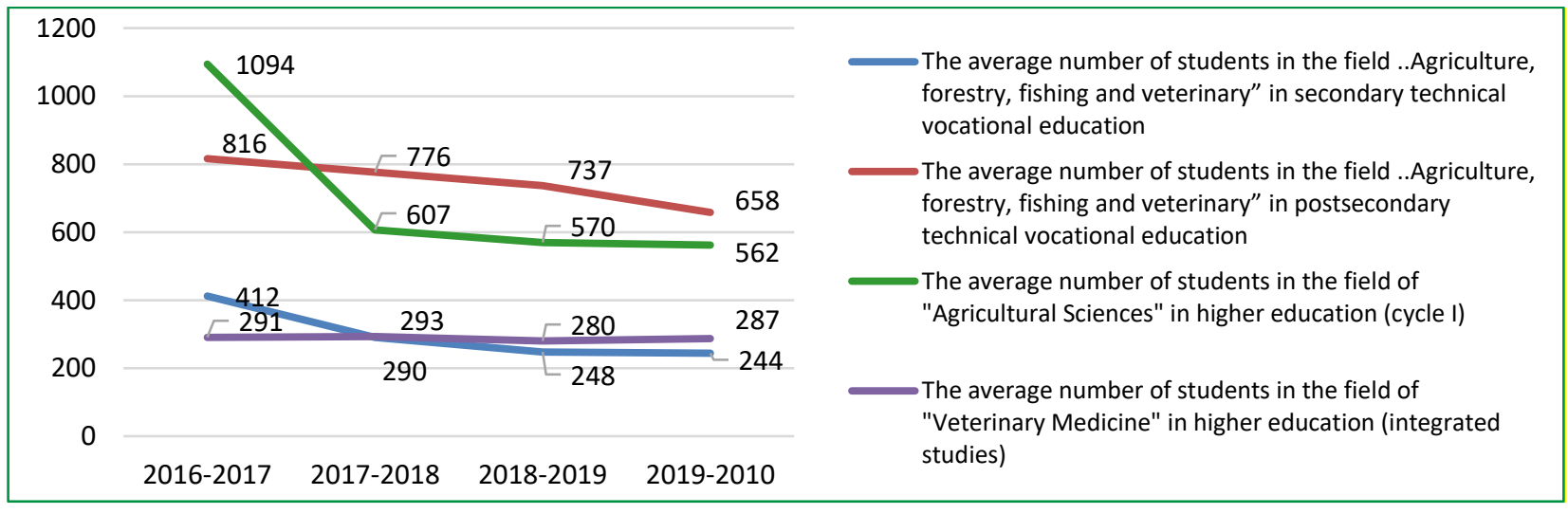

Figure 3. The average number of agricultural program students in the Republic of Moldova in the 2016-2010 period, pers.

Source: Developed by the authors based on [NBSRM. Education and science].

December No. 2/2020 


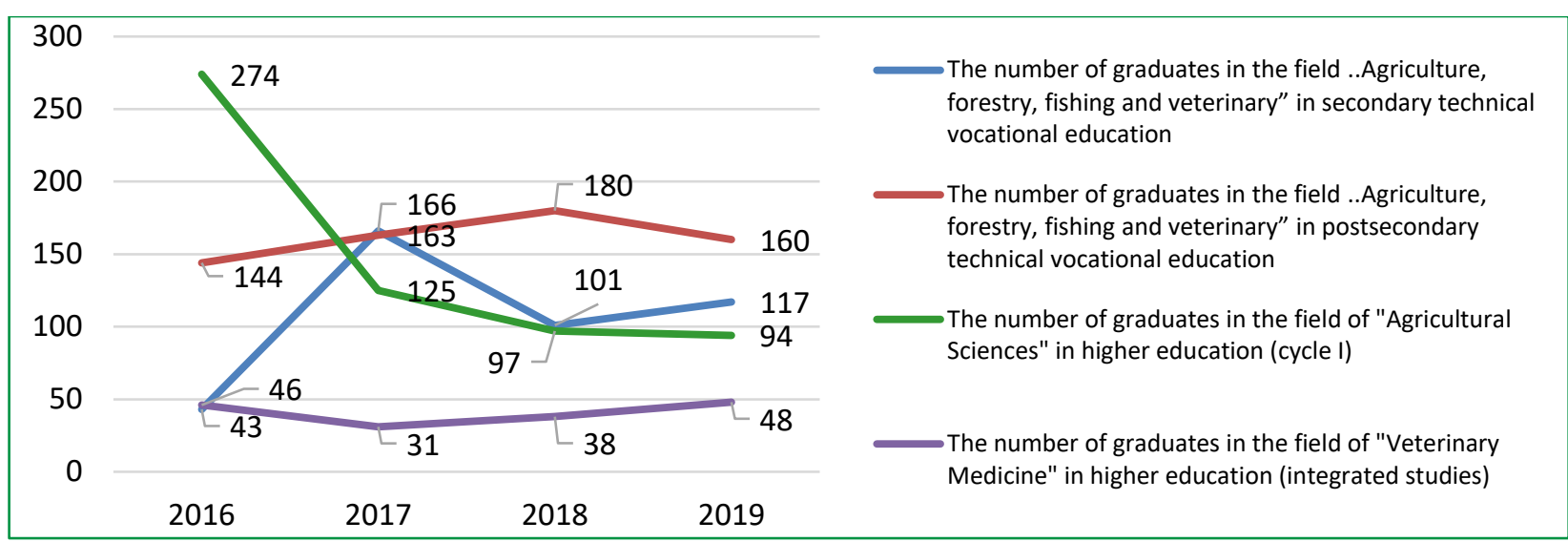

Figure 4. The number of agricultural program graduates

in the Republic of Moldova in the 2016-2019 period, pers. Source: Developed by the authors based on on [NBSRM. Education and science].

Descending trends in the number of graduates, along with the low level of employment according to their qualification, lead to a shortage of skilled labor in the sector [Prisacaru et al., 2019; Buciuceanu-Vrabie and Gagauz, 2017]. The quantitative insufficiency of qualified personnel in the agricultural production sector is not the only problem related to the transfer of professional education performance in the real sector, another important problem being unsatisfactory competencies. At the same time, it would be erroneous to say that the issue of connecting the competences offered by professional education institutions with agricultural profile in the Republic of Moldova is new, being widely addressed at different levels [National Strategy for Agricultural and Rural Development, 2014-2020; The concept regarding the restructuring of the research, innovation, education and rural extension system in the agri-food field]. However, the persistence of this problem, as evidenced by the low satisfaction of employers with the quality of professional education [Prisacaru et al., 2019] denotes the reduced effectiveness of the efforts made up to the current stage. Based on the latest reasoning, there is a clear need for better clarification of the necessary interventions in the study programs, an important step in this regard being to clarify the existing problems in the evolution of the sector and to identify the necessary curricular interventions.

The sector evolution analysis, based on quantitative and qualitative indicators, is one of the recommended methods of the sectoral approach which, having a number of disadvantages as shown in Figure 1, has also a series of benefits by highlighting the drivers of change in the sector - new trends in technology, trends in international business and the context in which the sector operates (Wilson et al., 2016:26). Without diminishing the significance of other tools that need to be operated and that should complement the sector analysis, we must recognize that the evaluation of the sectoral indicators trends is an indispensable component of competence anticipation process. Already at the stage of examining the quantitative and qualitative trends found out in the sector evolution, and of problems and factors determining them, a series of directions of intervention in professional education programs can be designed, thus making an essential contribution to the quality of those programs.

Harnessing the trends in the sector evolution as a tool to rationalize professional education offer is possible by understanding the interdependence between economic indicators and the factors of different nature conditioning them. On the basis of detailed examination of the factors, the areas where professional education institutions can improve the competences of the future managers and specialists can be identified.

The data on the evolution of agricultural production in the Republic of Moldova show the absence of increasing trends of the sector performance, a first sign being the negative tendency of the contribution of agriculture, forestry and fishing in GDP (Figure 5). Thus, we find out that, if in 2014 the sector's contribution in GDP was $12.2 \%$, it continuously decreased later, being only $10.3 \%$ in 2018. In the absence of available statistical data for the last two years (2019 and 2020), due to the 
drought faced by the Republic of Moldova in 2020 and the economic crisis caused by the pandemic, it is obvious that we can not expect an improvement of the situation, but rather the opposite.

\begin{tabular}{|c|c|c|c|c|c|c|c|c|c|}
\hline \multirow{2}{*}{$\begin{array}{r}15 \\
10 \\
5\end{array}$} & $\ulcorner 11.2$ & 「 11.4 & 10.4 & 11.6 & -12.2 & Г 11.5 & $\lceil-11.4$ & 11.5 & 10.3 \\
\hline & 2010 & 2011 & 2012 & 2013 & 2014 & 2015 & 2016 & 2017 & 2018 \\
\hline
\end{tabular}

Figure 5. The contribution of agriculture, forestry and fishing in the GDP of the Republic of Moldova in the $2010-2018$ period, $\%$

Source: Developed by the authors based on [NBSRM. National accounts].

Another significant aspect that reveals the prosperity of any sector is the evolution of the gross added value generated per employed person (Figure 6). Examining the evolution of the indicator over a period of eight years, we note a very slow rise, and the level of only 46.6 thousand lei reached in 2018.

\begin{tabular}{|c|c|c|c|c|c|c|c|c|}
\hline 50 & -31.3 & 29.5 & $\ulcorner-47.9$ & -41.5 & -37 & -48.3 & 50.9 & 46.6 \\
\hline & 2011 & 2012 & 2013 & 2014 & 2015 & 2016 & 2017 & 2018 \\
\hline
\end{tabular}

Figure 6. Gross value added per person employed in agriculture, forestry and fishing in the Republic of Moldova in the 2011-2018 period, thousand lei (comparable prices)

Source: Developed by the authors based on [NBSRM. National accounts. Gross domestic product; NBSRM. Labour force].

One of the important criteria for a sector performance is its contribution to exports. As we note in Figure 7, the share of agricultural products in total exports has fluctuating trends, registering its significant reduction in 2018, while the share of imported agricultural products had slow, but steady growth trends.

\begin{tabular}{|c|c|c|c|c|c|c|c|c|c|}
\hline 50 & 23.85 & $\digamma 22.96$ & Г 18.42 & -22.41 & -26.05 & -27.42 & -27.86 & $\ulcorner 29.26$ & 27.06 \\
\hline \multirow[t]{2}{*}{0} & $\begin{array}{l}E 6.84 \\
2010\end{array}$ & $2011^{5.91}$ & 2012 & 2013 & 2014 & 2015 & 2016 & $2017^{6.76}$ & $L_{2018} 6.95$ \\
\hline & & & $\begin{array}{l}\text { The share } \\
\text { The share }\end{array}$ & $\begin{array}{l}\text { e of agricult } \\
\text { e of agricult }\end{array}$ & $\begin{array}{l}\text { ural produc } \\
\text { ural produc }\end{array}$ & $\begin{array}{l}\text { ts in total e } \\
\text { ts in total in }\end{array}$ & $\begin{array}{l}\text { iports } \\
\text { iports }\end{array}$ & & \\
\hline
\end{tabular}

Figure 7. Comparative analysis of the share of agricultural products in total imports and exports of the Republic of Moldova in the 2010-2018 period, $\%$

Source: Developed by the authors based on [NBSRM. External trade].

Crop production is a branch that the economy of the Republic of Moldova relies on, especially as a result of the decline in the livestock production generated by the privatization process. The first step in the analysis of the crop production evolution consists in the estimation of its production potential, an important element of which are the agricultural areas of various categories. In this context, the trends in perennial plantations areas as well as those cultivated with vegetables have a special significance, fruit and vegetables representing high value crops, on which a greater stake is placed (Tables 1 and 2). 
Table 1

Evolution of perennial plantation areas in the Republic of Moldova in the 2010-2018 period

\begin{tabular}{|l|c|c|c|c|c|c|c|c|c|}
\hline Indicators & 2010 & 2011 & 2012 & 2013 & 2014 & 2015 & 2016 & 2017 & 2018 \\
\hline $\begin{array}{l}\text { Total fruit, berries and nuts } \\
\text { plantations, thousand ha }\end{array}$ & 116 & 119 & 120 & 122 & 122 & 136 & 135 & 138 & 140 \\
\hline $\begin{array}{l}\text { incl. in agricultural enterprises } \\
\text { of all types }\end{array}$ & 53.9 & 54.5 & 55.8 & 56.7 & 64.2 & 63.8 & 61.5 & 64.1 & 65.8 \\
\hline $\begin{array}{l}\text { Share of fruit, berry and nut } \\
\text { plantations of the agricultural } \\
\text { enterprises in the total area of } \\
\text { respective plantations, \% }\end{array}$ & 46.47 & 45.80 & 46.50 & 46.48 & 52.62 & 46.91 & 45.56 & 46.45 & 47.00 \\
\hline $\begin{array}{l}\text { Total area of vineyards, } \\
\text { thousand ha }\end{array}$ & 145 & 140 & 141 & 137 & 140 & 135 & 135 & 130 & 133 \\
\hline $\begin{array}{l}\text { incl. in agricultural enterprises } \\
\text { of all types }\end{array}$ & 36.8 & 35.1 & 34.3 & 32.1 & 31.9 & 30.5 & 30.4 & 30.5 & 30.9 \\
\hline $\begin{array}{l}\text { Share of vineyard of the } \\
\text { agricultural enterprises in the } \\
\text { total area of vineyards, } \%\end{array}$ & 25.38 & 25.07 & 24.33 & 23.43 & 22.79 & 22.59 & 22.52 & 23.46 & 23.23 \\
\hline
\end{tabular}

Source: Developed by the authors based on [NBSRM. Agriculture. Crop production].

According to the data in Table 1, the plantations of fruit trees, nuts and berries increased continuously in the analyzed period (2010-2018), reaching the level of 140 thousand ha in 2018. Thus there is an absolute increase of the respective areas of 24 thousand ha equivalent to a growth rate of $120.7 \%$. Areas managed by agricultural enterprises had the same trend, the growth rate being $122.1 \%$. Total vineyard area decreased by $8.28 \%$, including those managed by enterprises - by $16 \%$. Regarding the share of area with perennial crops managed by enterprises in the total areas, we can see that in the analyzed period it did not vary substantially.

Evolution of the areas cultivated with vegetables in the Republic of Moldova in the period 2010-2018

\begin{tabular}{|l|c|c|c|c|c|c|c|c|c|}
\hline Indicators & 2010 & 2011 & 2012 & 2013 & 2014 & 2015 & 2016 & 2017 & 2018 \\
\hline $\begin{array}{l}\text { Total areas cultivated with } \\
\text { vegetables, thousand ha }\end{array}$ & 77 & 73 & 65 & 66 & 63 & 57 & 59 & 57 & 53 \\
\hline $\begin{array}{l}\text { incl. in agricultural enterprises of } \\
\text { all types }\end{array}$ & 15.2 & 12.8 & 10.6 & 9.4 & 9.8 & 7.4 & 8.2 & 6.9 & 6.5 \\
\hline $\begin{array}{l}\text { Share of areas cultivated with } \\
\text { vegetables of the enterprises in } \\
\text { the total area,\% }\end{array}$ & 19.74 & 17.53 & 16.31 & 14.24 & 15.56 & 12.98 & 13.90 & 12.11 & 12.26 \\
\hline
\end{tabular}

Source: Developed by the authors based on [NBSRM. Agriculture. Crop production].

According to the data in Table 2, the areas cultivated with vegetables decreased continuously during the researched period, the level reached in 2018 being by 24 thousand ha below the level of 2010 , which means a reduction by $31.16 \%$. At the same time, we notice an even more substantial reduction, by over $57 \%$, in the vegetable areas of agricultural enterprises. Due to the potential value of vegetables, along with other special meanings (e.g. as a food product, as raw material for the processing industry, etc.), the stated trends can certainly be considered an alarm signal for decision makers on the strategic direction of the sector.

By generalizing the data on the evolution of agricultural areas, we can positively appreciate the increase of the areas of perennial plantations in the investigated period. At the same time, based on the economic significance of perennial crops, we can deduce that the growth rate of areas of only $120.7 \%$ in a period of nine years is insufficient. The reduction of areas cultivated with vegetables is another problem of the sector with a negative impact on its performance.

In order to highlight the economic results of the crop production, we will initially elucidate the trends in the evolution of the global crop production (Figure 8) and the crop production index (Figure 9). 


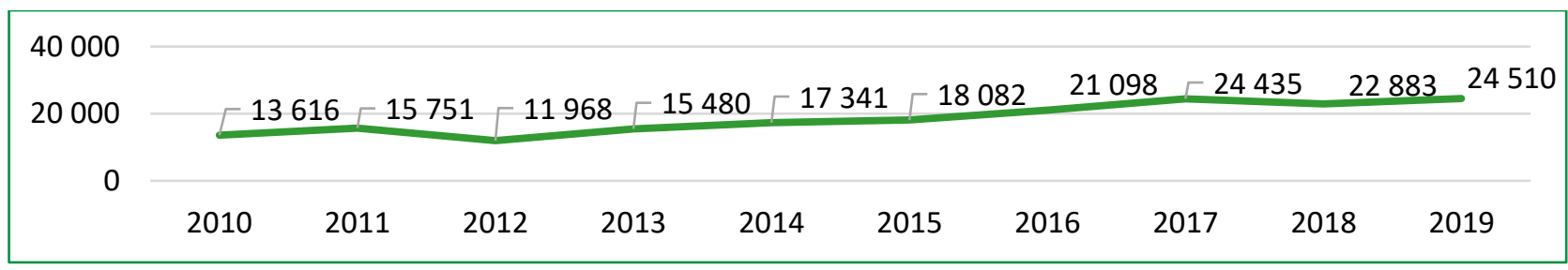

Figure 8. Evolution of the global crop production in the Republic of Moldova in the 2010-2019 period, million lei

Source: Developed by the authors based on [NBSRM. Agriculture. Crop production].

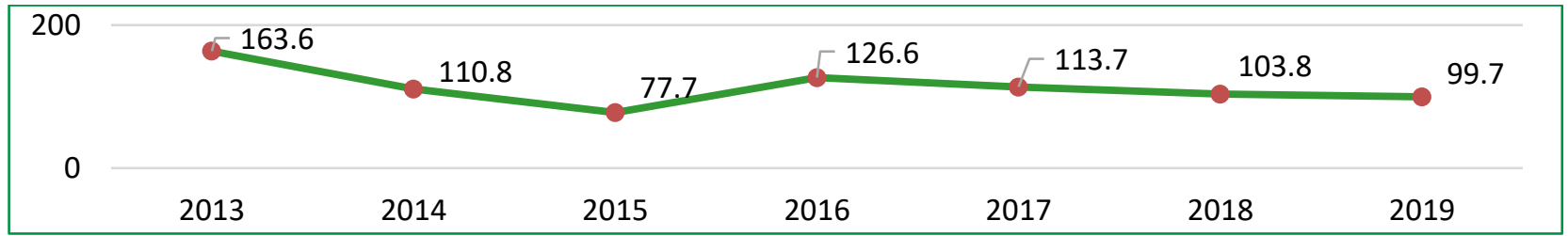

Figure 9. Evolution of the crop production index

in the Republic of Moldova in the 2013-2019 period, \%

Source: Developed by the authors based on [NBSRM. Agriculture. Crop production].

According to the data presented in Figure 8, we notice the increasing trends in the crop production value. Thus, despite the reduction of the indicator in 2012 and 2018 compared to previous years, the level reached in 2019 is higher than that recorded in 2010, the total growth rate (for nine years) being $180 \%$. However, the indicators set out in Figure 8 cannot serve as indisputable evidence of the increase in crop production performance under the following circumstances:

- the crop production index, as we notice from figure 9, did not have continuous growth tendencies, being ascertained even its continuous reduction starting with the year 2016;

- global crop production is an indicator that expresses the result, but not the economic efficiency of the brunch.

In order to deepen the study, we will use the "crop yields" indicator which provides a more accurate picture of the quality of the production factors` management (Table 3 ).

Table 3

Crop yields in the Republic of Moldova in the period 2010-2019, quintals/ha

\begin{tabular}{|l|c|c|c|c|c|c|c|c|c|}
\hline \multicolumn{1}{|c|}{ Indicators } & $\mathbf{2 0 1 0}$ & $\mathbf{2 0 1 1}$ & $\mathbf{2 0 1 2}$ & $\mathbf{2 0 1 3}$ & $\mathbf{2 0 1 4}$ & $\mathbf{2 0 1 5}$ & $\mathbf{2 0 1 6}$ & $\mathbf{2 0 1 7}$ & $\mathbf{2 0 1 8}$ \\
\hline $\begin{array}{l}\text { Cereal and legume } \\
\text { crops }\end{array}$ & 22.3 & 25.4 & 14.3 & 30.8 & 34.0 & 25.1 & 35.0 & 39.2 & 37.9 \\
\hline Sugar beet & 326.6 & 240.1 & 191.4 & 358.6 & 501.6 & 255.5 & 329.0 & 381.8 & 386.5 \\
\hline Tobacco & 17.6 & 15.3 & 13.1 & 15.4 & 17.4 & 16.2 & 13.9 & 18.3 & 19.5 \\
\hline Sunflower & 15.4 & 15.7 & 10.3 & 20.5 & 18.4 & 15.5 & 19.8 & 21.8 & 22.3 \\
\hline Soy & 18.7 & 13.4 & 8.0 & 16.7 & 21.5 & 7.2 & 11.8 & 14.4 & 22.2 \\
\hline Potatoes & 130.9 & 152.3 & 105.9 & 157.7 & 184.3 & 114.7 & 139.5 & 149.7 & 142.6 \\
\hline Field vegetables & 67.1 & 88.5 & 73.6 & 88.8 & 105.1 & 115.2 & 138.1 & 142.2 & 130.4 \\
\hline Pumpkin food crops & 46.5 & 50.4 & 38.4 & 59.7 & 35.5 & 52.2 & 54.3 & 69.4 & 103.8 \\
\hline Roots for fodder & 275.9 & 264.4 & 204.1 & 273.2 & 404.0 & 272.9 & 143.4 & 41.5 & 35.6 \\
\hline $\begin{array}{l}\text { Corn for silage, green } \\
\text { mass and hay }\end{array}$ & 152.8 & 148.7 & 48.6 & 171.4 & 177.1 & 97.7 & 190.5 & 193.7 & 270.2 \\
\hline Seed fruits & 42.3 & 56.6 & 60.6 & 81.8 & 92.9 & 67.6 & 89.7 & 119.9 & 171.0 \\
\hline Stone fruits & 27.1 & 18.4 & 19.8 & 37.2 & 41.2 & 49.9 & 51.9 & 48.4 & 65.6 \\
\hline Nuts & 1.7 & 2.2 & 0.9 & 3.9 & 3.5 & 3.7 & 3.5 & 3.8 & 5.4 \\
\hline Berries & 8.7 & 8.6 & 10.8 & 10.5 & 17.0 & 11.0 & 14.5 & 19.5 & 27.8 \\
\hline Grapes & 23.1 & 44.8 & 40.5 & 62.1 & 51.3 & 53.3 & 62.3 & 79.0 & 86.0 \\
\hline
\end{tabular}

Source: Developed by the authors based on [NBSRM. Agriculture. Crop production].

Note: Data reflects the situation in agricultural enterprises. 
The data in Table 3 show an increase in the crop yields, with the exception of fodder roots. At the same time, we note that none of the crops shows a stable trend of increasing yields, with fluctuations being identified in its evolution. The modest results in the evolution of crop production are also confirmed by the efficiency indicators of the agricultural enterprises (Table 4).

Table 4

Evolution of financial results of agricultural enterprises in the Republic of Moldova in the period 2015-2018

\begin{tabular}{|l|c|c|c|c|}
\hline \multicolumn{1}{|c|}{ Indicators } & 2015 & 2016 & 2017 & 2018 \\
\hline Number of profitable enterprises, units & 1530 & 1935 & 2431 & 2479 \\
\hline Financial result of profitable enterprises, million lei & 1148.94 & 1731.69 & 2720.43 & 2136.42 \\
\hline Number of unprofitable enterprises, units & 1377 & 1254 & 1163 & 1431 \\
\hline Financial result of unprofitable enterprises, million lei & -1039.81 & -451.7 & -274.93 & -525.25 \\
\hline Total financial result before tax, million lei & 109.13 & 1279.99 & 2445.50 & 1611.16 \\
\hline
\end{tabular}

Source: Developed by the authors based on [NBSRM. Entrepreneurship].

The data in Table 4 show the increase in the number of enterprises that operated profitably during the analyzed period, but also the continued existence of an impressive number of unprofitable enterprises. Through a more detailed investigation (Figure 10) we can see that in 2018 the share of profitable enterprises was $60.67 \%$. Even if, compared to the level of 2015, in 2018 the share of profitable enterprises increased by $10.19 \mathrm{pp}$, there are no stable trends in their share. At the same time, during the analyzed period a significant part of enterprises operated with losses, as we note in Figure 11. In the evolution of the total financial result, as well as, distinctly, of the profit obtained by the profitable enterprises and the losses of other category of enterprises, we also note the absence of stable improvement trends.

\begin{tabular}{|r|cccc|}
\hline 100 & & & 65.3 & 60.67 \\
50 & 50.48 & 58.32 & & \\
0 & & & & 2018 \\
\hline
\end{tabular}

Figure 10. Evolution of the share of profitable agricultural enterprises in the period 2015-2018, \%

Source: Developed by the authors based on [NBSRM. Entrepreneurship].

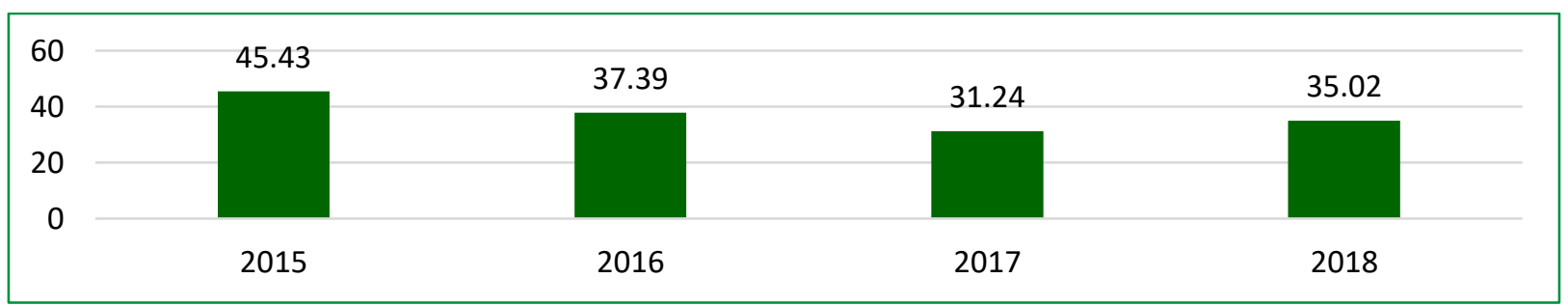

Figure 11. Evolution of the share of unprofitable agricultural enterprises

in the period $2015-2018, \%$

Source: Developed by the authors based on [NBSRM. Entrepreneurship].

By examining the "average profit per employee" indicator (Figure 12) we can see the same trends as in the total financial results of agricultural enterprises: while there is a steady increase in the indicator in the 2015-2017 period, 2018 was marked by its substantial reduction (by 33.8\%). 


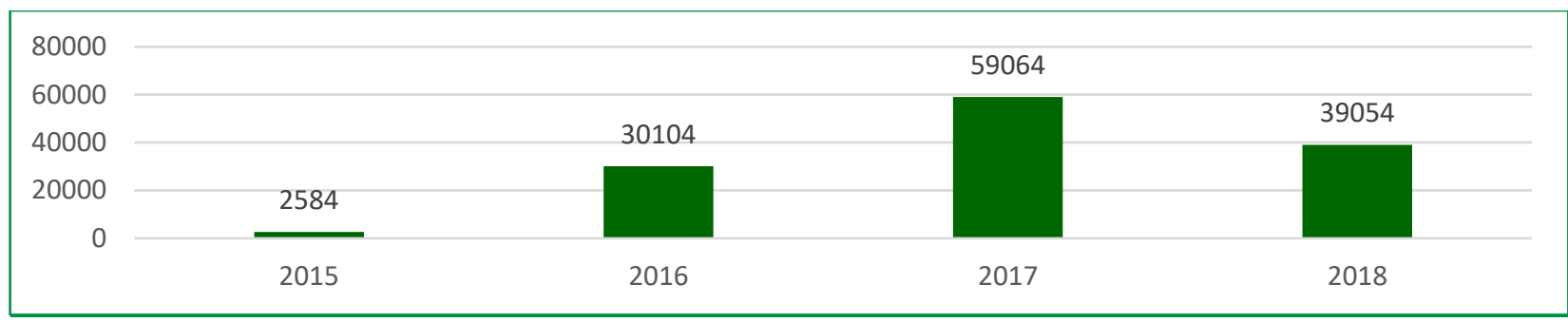

Figure 12. Evolution of the average profit per employee in agricultural enterprises in the $2015-2018$ period, lei

Source: Developed by the authors based on [NBSRM. Entrepreneurship].

By generalizing the presented above, we deduce the modest performance of agricultural production in general and of the crop production in particular, as well as the absence of visible positive trends in their evolution. The synthesis of some analytical studies on the subject reveals a series of factors conditioning the low profitability of crop production (Table 5).

\section{Factors conditioning the low profitability of crop production}

Table 5 in the Republic of Moldova

\begin{tabular}{|c|c|}
\hline $\begin{array}{l}\text { Groups of factors } \\
\text { according to their } \\
\text { nature }\end{array}$ & The factors' content \\
\hline Technological factors & $\begin{array}{l}\text { - The dominant position of low value crops (cereals, oilseeds, sugar beet); } \\
\text { - Low level of application of modern agricultural technologies (drought-resistant } \\
\text { varieties, hail protection tools, etc.); } \\
\text { - Insufficient irrigation capacity. }\end{array}$ \\
\hline Managerial factors & $\begin{array}{l}\text { - Dual and fragmented structure of agricultural enterprises; } \\
\text { - Poorly developed risk management tools; } \\
\text { - Lack of knowledge in product promotion. }\end{array}$ \\
\hline $\begin{array}{ll}\text { Economic } & \text { and } \\
\text { financial factors }\end{array}$ & $\begin{array}{l}\text { - Relatively high local production costs; } \\
\text { - Much lower productivity of agricultural crops compared to the EU countries; } \\
\text { - Limited share of investments in agriculture; } \\
\text { - Limited share of foreign capital in long-term active investments; } \\
\text { - High interest rates on bank loans and the short period of time for which loans are } \\
\text { offered; } \\
\text { - Lack of conditions and of infrastructure for storing products; } \\
\text { - Lack of the necessary resources to carry out at least partial processing of } \\
\text { production. }\end{array}$ \\
\hline $\begin{array}{l}\text { Factors regarding the } \\
\text { state mechanisms for } \\
\text { managing the sector }\end{array}$ & $\begin{array}{l}\text { - Long and expensive procedures for registering varieties; } \\
\text { - Instability of legislation, which increases business costs and creates difficulties in } \\
\text { making forecasts for longer periods of time; } \\
\text { - Instability of the country's policy in the field of international cooperation. }\end{array}$ \\
\hline Market factors & $\begin{array}{l}\text { - Monopoly on the local market by large companies that do not allow producers to } \\
\text { market their products at advantageous prices; } \\
\text { - Difficulties in penetrating new markets; } \\
\text { - High competition in foreign markets; } \\
\text { - Underdevelopment of the land market. }\end{array}$ \\
\hline Natural & - Unfavorable weather conditions. \\
\hline
\end{tabular}

Source: Developed by the authors based on [National Strategy for Agricultural and Rural Development, 2014-2020; Lupusor et all 2017; Stihi and Zatic, 2016].

Through the synthetic evaluation of the data presented in Table 5 we can conclude that the crop production efficiency can be increased through a system of complex and varied measures of technological, economic-financial, organizational, managerial, legislative-normative nature, etc., 
which, in their turn, require active and effective involvement of several actors and an optimal synergy of their efforts. Last but not least, we must mention the multitude of "cause-effect" relationships between various factors analyzed. For example, high production costs (economic factor) generate difficulties in penetrating products into markets, including external ones (market factor). On the other hand, the deficiencies in the application of advanced technologies (as a technological factor) are determined both by insufficient knowledge of advanced technologies (managerial factor) and by insufficient financial resources as a result of limited self-financing possibilities and difficulties in attracting external resources (financial factors). Based on the above mentioned, we also deduce the multiple effects of the same possible measures and, therefore, the special significance of those measures for the prosperity of the analyzed branch. Among them, we will emphasize in particular the better quality of agricultural education and training. In this context, based on the previously presented problems related to crop production, and using the objectives tree technique, we will schematically represent the recommendations for improving agricultural education programs and the expected medium and long term results (Figure 13).

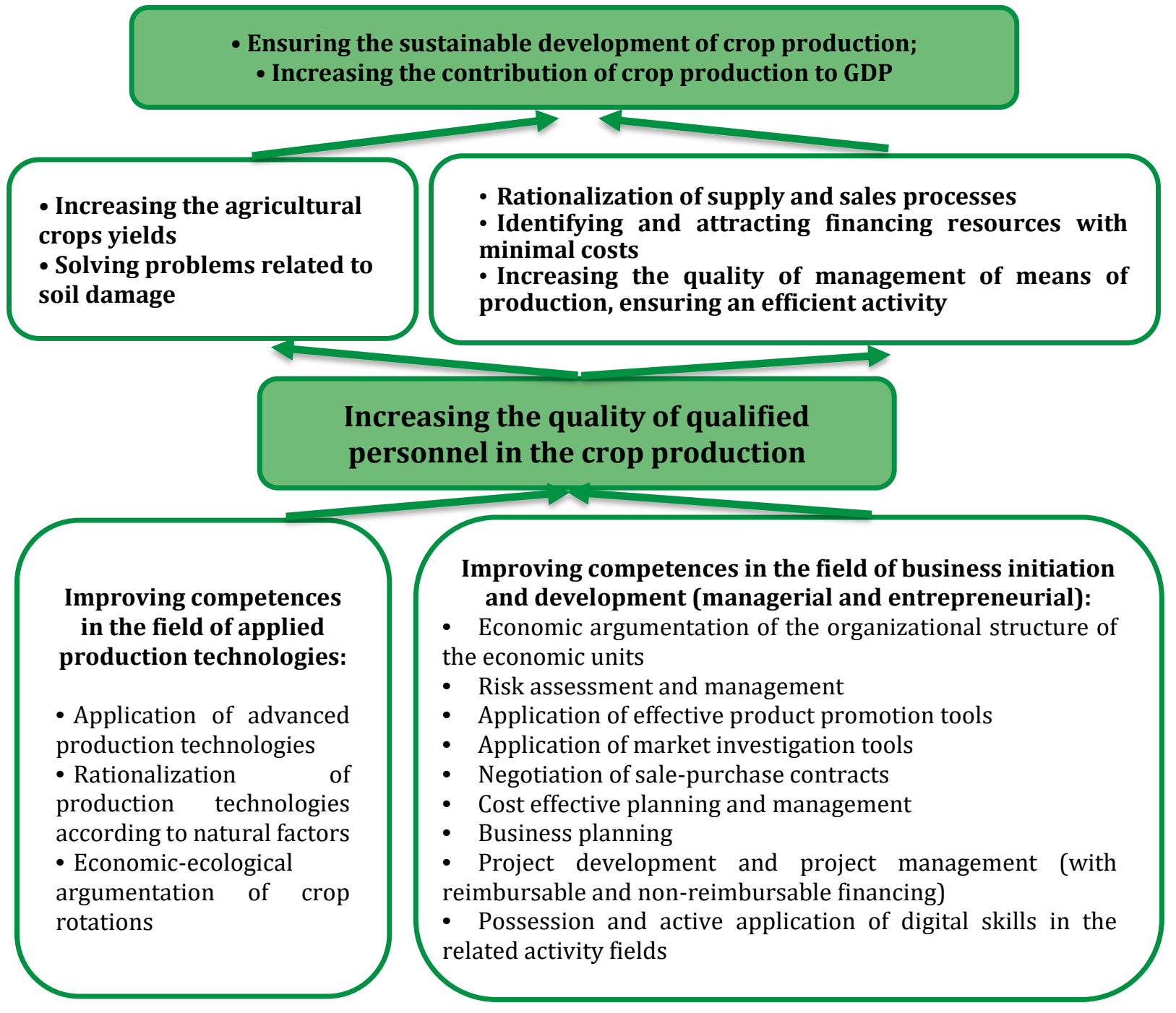

Figure 13. The tree of agricultural education objectives regarding the improvement of competences in the field of crop production

Source: Developed by the authors.

As shown in Figure 13, based on the problems that appeared in the evolution of the crop production, a number of objectives can be identified, and namely: objectives aimed at applying 
production technologies and objectives related to improving managerial and entrepreneurial competences. The effects of improving the related study programs are systematized in medium term effects (increasing crop yields, increasing soil fertility, streamlining supply and sales processes; identifying and attracting financing resources with minimal costs; increasing the quality of production management, ensuring efficient activity), and leading to the long-term effect (ensuring the sustainable development of the branch and increasing its contribution to GDP).

It should be noted that much of the competences needed to be improved in agricultural professional education programs in the Republic of Moldova are analogous to international concerns in this regard under the following circumstances: the sector will increasingly face both threats and opportunities because of climate changes. Thus, the agriculture is seen as the sector providing benefits and services over and above the production of commodities (UK Commission for Employment and Skills, 2012). But at the same time, advanced skills will be required, especially in the application of technologies adapted to environmental regulations. The skills of efficient business management are also widely addressed, thus creating premises for business continuity.

CONCLUSIONS

The data obtained as a result of the analysis of crop production in the Republic of Moldova as a tool of sectoral approach to anticipating competences, shows the existence of a wide range of problems that hinder the development and, respectively, the competitiveness of the branch. Solving the problems related to the agricultural production efficiency in general and to the crop production efficiency in particular, requires a series of measures of economic, managerial, normative and legislative nature, etc., as well as the involvement of a wide list of actors representing various fields and levels. Among them, agricultural education institutions are meant to contribute by providing better competences to future managers and specialists, so as to overcome or at least to diminish a number of problems in the sector.

Based on the problems appeared in the development of crop production, we can identify the following competences, on which greater emphasis must be placed in the process of professional education:

I. In the field of applied production technologies:

- Application of advanced production technologies;

- Rationalization of production technologies according to natural factors;

- Economic-ecological argumentation of crop rotations.

I. In the field of business initiation and development:

- Economic argumentation of the organizational structure of the economic units;

- Risk assessment and management;

- Application of effective product promotion tools;

- Application of market investigation tools;

- Negotiation of sale-purchase contracts;

- Cost effective planning and management;

- Business planning;

- Project development and project management (with reimbursable and non-reimbursable financing);

- Possession and active application of digital skills in the related activity fields.

Improving the competencies mentioned above is an important step in increasing the quality of the professional education process.

\section{REFERENCES}

1. Strategia Naţională de dezvoltare agricolă şi rurală pentru anii 2014-2020: nr. 409 din 04.06.2020. In: Monitorul Oficial al Republicii Moldova. 2014, nr. 152, art. 451 [cited 12 february 2020]. Available: https://www.legis.md/cautare/getResults?doc_id=110039\&lang=ro

2. BOGUSH, L. Directions of modernization of Ukrainian educational system in the context of increasing youth competitiveness on the labour market. In: Economie şi Sociologie = Economy and sociology. 2017, nr. 3, pp. 102-114. ISSN 1857-4130, E-ISSN 2587-3172.

3. BUCIUCEANU-VRABIE, M., GAGAUZ, O. Tinerii pe piața muncii din Republica Moldova: 
competențe și aspirații. Chișinău, 2017. 36 p. ISBN 978-9975-89-078-6.

4. CEDEFOP. Future skill needs in Europe: critical labour force trends. Luxembourg, 2016 [cited 06 may 2020]. Available: http://www.cedefop.europa.eu/files/5559_en.pdf

5. Concepția privind restructurarea sistemului de cercetare-inovare, educație și extensiune rurală în domeniul agroalimentar [cited 05 may 2020]. Available:

https://cancelaria.gov.md/sites/default/files/document/attachments/proiectul_158.pdf

6. LUPUȘOR, A. et al. Republica Moldova 2017: raport de stare a țării. Chișinău, 2017 [cited 05 may 2020]. Available: http://fes-

moldova.org/fileadmin/user_upload/2017/publications/RST_2017_ro.pdf

7. INTERNATIONAL LABOUR ORGANIZATION. Skills for trade and economic diversification.

Malawi: sector selection process [cited 01 may 2020]. Available:

https://www.ilo.org/wcmsp5/groups/public/---ed_emp/---

ifp_skills/documents/projectdocumentation/wcms_558763.pdf

8. GREGG, C., NAYEF, M. Skills for Trade and Economic Diversification (STED): Pharmaceutical

Sector. International Labour Organization. Beirut: ILO, 2015. 46 p. ISBN 978-92-2-130336-7,

ISBN 978-92-2-130337-4 [cited 02 may 2020].

Available: https://www.ilo.org/wcmsp5/groups/public/---ed_emp/---

ifp_skills/documents/publication/wcms_550993.pdf

9. INTERNATIONAL LABOUR ORGANIZATION. R 195 - Human Resources Development

Recommendation. 2004, no. 195 [cited 05 may 2020]. Available:

https://www.ilo.org/dyn/normlex/en/f?p=NORMLEXPUB:12100:0::NO::P12100_ILO_CODE:

R195

10. INTERNATIONAL LABOUR ORGANIZATION. A Skilled Workforce for Strong, Sustainable and Balanced Growth: A G20 Training Strategy. Geneva, 2010 [cited 05 may 2020]. Available: https://www.ilo.org/wcmsp5/groups/public/---ed_emp/---

ifp_skills/documents/publication/wcms_151966.pdf

11. INTERNATIONAL LABOUR ORGANIZATION. Upskilling out of the Downturn: Global Dialogue Forum on Strategies for Sectoral Training and Employment Security. Sectoral Activities

Programme: final report. 2010, 29-30 march [cited 15 march 2020]. Available:

https://www.ilo.org/wcmsp5/groups/public/---ed_norm/---

relconf/documents/meetingdocument/wcms_146292.pdf

12. INTERNATIONAL LABOUR ORGANIZATION ${ }^{6}$. Questions and answers: How a sectoral approach to skills development helps contribute to productive and competitive economies. 2016, 13 june [cited 08 june 2020]. Available: http://www.ilo.org/skills/pubs/WCMS_490204/lang-en/index.htm?shared_from=shr-tls

13. KLIEME, E., HARTIG, J., RAUCH, D. The concept of competence in educational contexts.

Hogrefe\&Huber Publishers, 2008 [cited 09 june 2020].

Available: https://www.researchgate.net/publication/232495759_The_concept_of_competenc e_in_educational_contexts

14. NATIONAL BUREAU OF STATISTICS OF THE REPUBLIC OF MOLDOVA ${ }^{1}$. Education and science [cited 15 march 2020]. Available: https://statistica.gov.md/category.php?l=en\&idc=116

15. NATIONAL BUREAU OF STATISTICS OF THE REPUBLIC OF MOLDOVA ${ }^{2}$. National accounts [cited 15 march 2020]. Available: https://statistica.gov.md/category.php?l=en\&idc=191

16. NATIONAL BUREAU OF STATISTICS OF THE REPUBLIC OF MOLDOVA3. National accounts. Gross domestic product. By resource categories [cited 17 march 2020].

Available: https://statistica.gov.md/category.php?l=ro\&idc=191

17. NATIONAL BUREAU OF STATISTICS OF THE REPUBLIC OF MOLDOVA4. Labour force [cited 18 march 2020]. Available: https://statistica.gov.md/category.php?l=en\&idc=107

18. NATIONAL BUREAU OF STATISTICS OF THE REPUBLIC OF MOLDOVA ${ }^{5}$. External trade. Foreign trade [cited 18 march 2020]. Available: https://statistica.gov.md/category.php?l=en\&idc=336\#

19. NATIONAL BUREAU OF STATISTICS OF THE REPUBLIC OF MOLDOVA6 . Agriculture. Crop production [cited 19 march 2020].

Available: https://statistica.gov.md/category.php?l=en\&idc=129

December No. 2/2020 
20. NATIONAL BUREAU OF STATISTICS OF THE REPUBLIC OF MOLDOVA7 . Entrepreneurship. [cited 20 may 2020]. Available: https://statistica.gov.md/category.php?l=en\&idc=368

21. STIHI, L., ZATÎC, V. Analiza sectorului agroalimentar: studiul sectorial. Organizația pentru Dezvoltarea Sectorului Întreprinderilor Mici și Mijlocii. Chișinău, 2016. 30 p. [cited 03 may 2020]. Available: http://www.odimm.md/files/ro/pdf/publicatii/Analiza_Industria_agroalimentar.pdf

22. PRISACARU, V., BALTAG, G., SEVCIUC, T. Report on results of identifying the mid-term labour market demand for higher and vocational education in the area of: phytotechny, horticulture, pedology and soil protection, production of agricultural crops and livestock breeding, animal husbandry and veterinary medicine, products of plan origin technology. Chisinau, 2019. $82 \mathrm{p}$.

23. SAVELIEVA, G., PRODAN, M. The situation of vulnerable groups on the labour market in the Republic of Moldova. In: Economie şi Sociologie = Economy and sociology. 2018, vol. 1, pp. 113126. ISSN 1857-4130, E-ISSN 2587-3172.

24. BREUER, Z. Agriculture, Forestry and Fishing: Sector Skills Assessment 2012. UK Commission for Employment and Skills. Geneva, 2012, october. 234 p. [cited 22 january 2020]. Available: https://dera.ioe.ac.uk/15967/1/evidence-report-58-agriculture-ssa.pdf

25. WEINERT, F.E. Concepts of Competence. Germany, Munich: Max Planck Institute for Psychological Research, 1999 [cited 15 june 2020] Disponibil: https://pdfs.semanticscholar.org/8b88/efa9dd5e0a4b605aea6e5e3b9ec640beb089.pdf

26. WILSON, R.A., TARJÁNI, H., RIHOVA, H. Working at sectoral level. Guide to anticipating and matching skills and jobs. Geneva, 2016, vol. 3. 168 p. ISBN 978-92-9157-657-9 [cited 05 may 2020]. Available: https://www.etf.europa.eu/en/publications-andresources/publications/working-sectoral-level-guide-anticipating-and-matching

\section{ARTICLE HISTORY}

Received 25 May 2020

Accepted 19 October 2020 